\title{
Autosomal dominant coarctation of aorta
}

INSERM

\section{Source}

INSERM. (1999). Orphanet: an online rare disease and orphan drug data base. Autosomal dominant coarctation of aorta. ORPHA:1455

A number of families have been described, where several members were affected with coarctation of aorta. In a systematic study of coarctation, familial aggregation was considered as result of multifactorial inheritance and recurrence risks in sibs was evaluated at about $0.5 \%$ for coarctation and $1.0 \%$ for any form of congenital heart defect. Nevertheless, in some of the described families, aortic coarctations seems to be inherited as an autosomal dominant mutation. 